\title{
Pig Management System in Organized and Unorganized Farm in Jaipur and Alwar District of Rajasthan, India
}

\author{
B. Nanda*, M.P. Poonia, A. Sharma, S. Rajoria and S. Sharma \\ Department of Livestock Production Management, Post Graduate Institute of Veterinary \\ Education and Research, Jaipur - 302031, India \\ *Corresponding author:
}

A B S T R A C T

The study attempts to investigate the social status and husbandry practices of pig farmers in Jaipur and Alwar district of Rajasthan state, where 10 organized and 20 unorganized farms were selected. Population and production trend of pig husbandry in India and around the world reveled that pig population in India had consistently decreasing trend from 13.29 million (1997) to 10.29 million (2012) whereas world population showing increasing trend from 830.37 million to 969.89 million. Regarding socio-personal variable in present study

\section{Keywords}

Pig Management System, Social status, Husbandry practices

\section{Article Info}

Accepted:

15 July 2018

Available Online:

10 August 2018

it was shown that in organized sector maximum respondents $(75 \%)$ were middle aged and had Graduate $(80 \%)$ level of education whereas in unorganized sector maximum respondents $(65 \%)$ were middle aged and illiterate $(65 \%)$. Regarding housing practices the type of housing system was intensive $(65 \%)$ in organized farm with single slope roof $(70 \%)$ whereas in unorganized farm $(100 \%)$ respondents had semi-intensive system with flat roof $(100 \%)$. In feeding practices, stall feeding were practiced by $(100 \%)$ respondents in organized farm whereas in unorganized farm $(72.5 \%)$ respondents were followed the scavenging feeding practice. Regarding breeding practices in organized farm the breed of animals were crossbred (100\%), twice farrowing in a year reported by (100\%) respondents whereas in unorganized farm undescriptive breed was reared by $(92.5 \%)$ respondents, twice farrowing in a year reported by $(82.5 \%)$ respondents. Regarding healthcare practices, in organized farm deworming was irregular by $(80 \%)$ respondents, the most prevalent diseases were diarrhea reported by $(45 \%)$ respondents whereas in unorganized farm deworming was never done by $(100 \%)$ respondents, the most prevalent disease was diarrhea reported by $(77.5 \%)$ respondents. In organized farm the market weight of $100 \mathrm{~kg}$ recorded by $(75 \%)$ respondents, the market age of 10 -12 month reported by maximum $(80 \%)$ respondents, marketed through middleman and pig were mainly marketed in North eastern regions of India (55\%) whereas in unorganized farm the market weight of 50 -60 $\mathrm{kg}$ and market age of 5-7 month were reported by (100\%) respondents, and the main marketing area was local market.

\section{Introduction}

Animal products plays an important part in food security for its contribution as source of high quality, balanced bioavailable protein and numerous critical micronutrients, including iron, zinc, and vitamins. Thus, moderate consumption of animal-sourced food plays an 
important role in achieving a nutritionally balanced diet, especially in the developing world.

Pigs have been described as one of the most prolific and fast growing livestock species which can convert food waste to valuable products, excel in converting feed to meat compared to other red meat animals, such as cattle, sheep and goats (Vicente et al., 2011).

Rearing of pig in our country was earlier considered as the practice adopted by only economically and socially weaker (low caste) section of the society particularly in the mainland of the country, but with the passing of time, advancement of science and technology, problem of unemployment, increase gap between demand and supply of meat, other section of the society also started developing favorable attitude towards pig rearing.

In Rajasthan state, highest population was in Jaipur and Alwar district as 21.2 thousand and 15.1 thousand, respectively. So far no systematic study has been conducted in the region regarding husbandry practices and marketing in piggery sector in the state of Rajasthan. Considering the importance of pig rearing, the present study was conducted to find out the existing management practices and major constraints in pig farming in the selected areas.

\section{Materials and Methods}

The study was undertaken in two selected districts i.e. Alwar and Jaipur of Rajasthan. A total of 10 organized farms and 20 unorganized pig farms were randomly selected from each selected district for the study. The pig farms were categorized as organized and unorganized farm according to their pig rearing patterns. The organized pig farm for this study has been considered to be those pig farmers who adopted following criteria i.e. rearing more than 100 pigs and have a housing system and unorganized farmers were selected, irrespective of pig numbers. A questionnaire incorporating all the variables were designed in consultation with animal husbandry experts, to study the breeds of animals possessed by the respondents, variety of management practices under which pigs are reared had been incorporated in the questionnaire.

\section{Results and Discussion}

Salient observations of production and management practices followed by the farmers are presented in the Tables.

The results represented in Table 1 revealed that the majority of the respondents in organized and unorganized farm were belonged to middle age group (75\% and $65 \%$ ) followed by old $(15 \%$ and $15 \%)$ and young age group (10\% and 20\%), respectively. Similar findings were also reported by Kumar et al., (2004). It was observed that $80 \%$ of the respondents were graduate level and above while $20 \%$ upto intermediate in organized farm whereas in unorganized farm the respondents were illiterate $(65 \%)$, primary level $(7.5 \%)$, middle level (17.5\%), and high school level $(10 \%)$ as presented in table 1 . These finding is in conflicts with that of Sasikala et al.,(2012) and Fualefac et al.,(2014).

Regarding the housing practices it was observed that in organized farm the major housing type was intensive system (65\%) in which pigs were housed in separate pens according to their age group. About 35\% respondents were followed the semi intensive type of housing system whereas in unorganized farm the semi intensive type housing followed by $100 \%$ respondents (table 2 ). The above findings were in consonance 
with the findings of Machebeet al., (2009). The type of floor was concrete (Pacca) in both organized and unorganized farm $100 \%$ and $80 \%$, respectively. Roof type was Flat (100\%) in unorganized farm whereas single slope was provided by $70 \%$ respondents. These findings were in line with the findings of Ajala et al., (2007).

Most of the respondents (92.5\%) in unorganized sector were rearing indigenous / desi breed whereas in organize sector it was mostly $(100 \%)$ carried out with exotic and crossbreed (Middle white Yorkshire) animal (Table 3). It was shown that there was lack of artificial insemination for breeding and only natural service was the mean of breeding in both organized and unorganized sector. The present study was also supported by findings of Fualefac et al., (2014) and Deka et al., (2007). In organized sector $80 \%$ of the respondents had the ability to detect the heat whereas in unorganized sector 65\% respondents only (Table 3 ).

The results as presented in table 4, shown that the stall feeding was practiced only in organized farm by all the respondents whereas in unorganized sector most of the respondents $72.5 \%$ were followed the scavenging type of feeding practices and $27.5 \%$ respondents followed the scavenging with morning and evening ration to pig as observed by Njuki $e t$ al., (2010).

Table.1 Distribution of respondents according to their personal attributes

\begin{tabular}{|c|c|c|c|}
\hline \multirow{2}{*}{\multicolumn{2}{|c|}{ Personal attributes }} & \multirow{3}{*}{$\begin{array}{c}\text { Organized }(\mathrm{N}=20) \\
\text { Per cent } \\
10\end{array}$} & \multirow{3}{*}{$\begin{array}{c}\text { Unorganized }(\mathbf{N}=\mathbf{4 0}) \\
\text { Per cent } \\
20\end{array}$} \\
\hline & & & \\
\hline \multirow[t]{3}{*}{ Age } & Young (Up to 30 years) & & \\
\hline & Middle (31 to 50 years) & 75 & 65 \\
\hline & Old (Above 50 years) & 15 & 15 \\
\hline \multirow[t]{6}{*}{ Education } & Illiterate & 0 & 65 \\
\hline & Upto Primary level & 0 & 7.5 \\
\hline & Upto Middle level & 0 & 17.5 \\
\hline & Upto High school level & 0 & 10 \\
\hline & Upto Intermediate level & 20 & 0 \\
\hline & Graduate \& above & 80 & 0 \\
\hline \multirow[t]{4}{*}{ Occupation } & Agriculture & 45 & 0 \\
\hline & Service in government sector & 20 & 0 \\
\hline & Trade \& commerce & 35 & 45 \\
\hline & Labour & 0 & 55 \\
\hline \multirow[t]{3}{*}{ Family Size } & Small (<5 members) & 20 & 7.5 \\
\hline & Medium (6- 9 members) & 50 & 67.5 \\
\hline & Large (> 9 members) & 30 & 25 \\
\hline \multirow[t]{6}{*}{ Herd Size } & Small (upto 150) & 40 & - \\
\hline & Medium $(150-250)$ & 45 & - \\
\hline & High (more than 250) & 15 & - \\
\hline & Small (upto 3) & - & 25 \\
\hline & Medium $(3-8)$ & - & 52.5 \\
\hline & High (more than 8) & - & 22.5 \\
\hline
\end{tabular}


Table.2 Percentage of housing practices in the area

\begin{tabular}{|c|c|c|c|}
\hline \multirow{2}{*}{\multicolumn{2}{|c|}{ Variables }} & \multirow{3}{*}{$\begin{array}{c}\text { Organized } \\
\text { Per cent } \\
65\end{array}$} & \multirow{3}{*}{$\begin{array}{c}\text { Unorganized } \\
\text { Per cent } \\
0\end{array}$} \\
\hline & & & \\
\hline \multirow[t]{2}{*}{ Type of house } & Intensive & & \\
\hline & Semi- Intensive & 35 & 100 \\
\hline \multirow[t]{2}{*}{ Floor } & Kutcha & 0 & 20 \\
\hline & Pacca & 100 & 80 \\
\hline \multirow[t]{2}{*}{ Type of Roof } & Flat & 30 & 100 \\
\hline & Single slope & 70 & 0 \\
\hline \multirow[t]{3}{*}{ Roof Material } & R.C.C & 30 & 0 \\
\hline & Tin Shad & 70 & 37.5 \\
\hline & Stone Slab & 0 & 62.5 \\
\hline \multirow[t]{2}{*}{ Material used in walls } & Brick with lime/ cement & 100 & 67.5 \\
\hline & Brick with mud & 0 & 32.5 \\
\hline \multirow[t]{2}{*}{ Manger Feeding } & Yes & 100 & 27.5 \\
\hline & No & 0 & 72.5 \\
\hline \multirow[t]{2}{*}{ Ventilation } & Low & 20 & 100 \\
\hline & Optimum & 80 & 0 \\
\hline \multirow[t]{2}{*}{ Bedding material } & Yes & 35 & 0 \\
\hline & No & 65 & 100 \\
\hline \multirow[t]{2}{*}{ Light in farm } & Low & 35 & 65 \\
\hline & Optimum & 65 & 35 \\
\hline \multirow[t]{2}{*}{ Presence of guard rail } & Yes & 0 & 0 \\
\hline & No & 100 & 100 \\
\hline \multirow[t]{2}{*}{ Drainage system } & Efficient & 90 & 27.5 \\
\hline & Non-efficient & 10 & 72.5 \\
\hline
\end{tabular}

Table.3 Percentage of breeding practices in the area

\begin{tabular}{|c|c|c|c|}
\hline \multirow{2}{*}{\multicolumn{2}{|c|}{ Variables }} & \multirow{3}{*}{$\begin{array}{c}\text { Organized } \\
\text { Per cent } \\
100\end{array}$} & \multirow{3}{*}{$\begin{array}{c}\text { Unorganizec } \\
\text { Per cent } \\
7.5\end{array}$} \\
\hline & & & \\
\hline \multirow[t]{2}{*}{ Breed of swine } & Yorkshire & & \\
\hline & Non- descript & 0 & 92.5 \\
\hline \multirow[t]{2}{*}{ Service of sow } & Natural service with boars & 100 & 100 \\
\hline & Artificial insemination & 0 & 0 \\
\hline \multirow[t]{2}{*}{ Heat detection } & Yes & 80 & 65 \\
\hline & No & 20 & 35 \\
\hline \multirow[t]{2}{*}{ Castration } & Yes & 100 & 42.5 \\
\hline & No & 0 & 57.5 \\
\hline \multirow[t]{2}{*}{ Sow farrowed in a year } & Twice & 100 & 82.5 \\
\hline & More than twice & 0 & 17.5 \\
\hline \multirow[t]{2}{*}{ Litter size (in numbers) } & $4-6$ & 55 & 72.5 \\
\hline & $6-8$ & 45 & 27.5 \\
\hline \multirow[t]{2}{*}{ Time of weaning } & in 1 month & 35 & - \\
\hline & in $1-2$ month & 65 & - \\
\hline
\end{tabular}


Table.4 Percentage of Feeding Practices in the area

\begin{tabular}{|c|c|c|c|}
\hline \multicolumn{2}{|c|}{ Variables } & \multirow{2}{*}{$\begin{array}{l}\text { Organized } \\
\text { Per cent }\end{array}$} & \multirow{2}{*}{$\begin{array}{l}\text { Unorganized } \\
\text { Per cent }\end{array}$} \\
\hline & & & \\
\hline \multirow[t]{3}{*}{ Feeding of animal } & Stall feeding & 100 & 0 \\
\hline & Scavenging feeding & 0 & 72.5 \\
\hline & $\begin{array}{l}\text { Scavenging with morning and } \\
\text { evening ration }\end{array}$ & 0 & 27.5 \\
\hline \multirow{4}{*}{ Type of feed } & Kitchen waste & 0 & 27.5 \\
\hline & Hotel waste & 35 & - \\
\hline & Hostel waste & 40 & - \\
\hline & Mix. Of Hotel and Hostel waste & 25 & - \\
\hline \multirow[t]{2}{*}{ Process of purchasing } & Direct Purchasing & 45 & - \\
\hline & Presence of middleman & 55 & - \\
\hline \multirow{3}{*}{$\begin{array}{l}\text { Quantity of feed } \\
\text { provided (kg)/day }\end{array}$} & $20-30$ & 35 & - \\
\hline & $40-50$ & 55 & - \\
\hline & $50-70$ & 10 & - \\
\hline \multirow[t]{4}{*}{ Additional Feeding } & Vegetables & 50 & - \\
\hline & Cereal grain & 5 & - \\
\hline & Mill by products & 25 & - \\
\hline & Mixture of all & 20 & - \\
\hline \multirow[t]{2}{*}{ Frequency of feeding } & Once & 0 & - \\
\hline & Twice & 100 & - \\
\hline
\end{tabular}

Table.6 Percentage of marketing area and pattern

\begin{tabular}{|c|c|c|c|}
\hline \multicolumn{2}{|c|}{ Variables } & \multirow{2}{*}{$\begin{array}{c}\text { Organized } \\
\text { Percent }\end{array}$} & \multirow{2}{*}{$\begin{array}{c}\text { Unorganized } \\
\text { Percent }\end{array}$} \\
\hline & & & \\
\hline \multirow[t]{3}{*}{ Selling weight(kg) } & $50-60$ & 0 & 100 \\
\hline & 100 & 75 & 0 \\
\hline & 120 & 25 & 0 \\
\hline \multirow[t]{3}{*}{ Selling age $\quad$ (month) } & $5-7$ & 0 & 100 \\
\hline & $9-10$ & 20 & 0 \\
\hline & $10-12$ & 80 & 0 \\
\hline \multirow[t]{2}{*}{ Sale price $(\mathrm{Rs} / \mathrm{kg})$} & $\leq 100$ & 80 & 30 \\
\hline & $>100$ & 0 & 70 \\
\hline \multirow{3}{*}{$\begin{array}{c}\text { Quantity of animal in a } \\
\text { batch }\end{array}$} & 50 & 25 & 0 \\
\hline & 100 & 60 & 0 \\
\hline & 150 & 15 & 0 \\
\hline \multirow[t]{2}{*}{ Presence of middle man } & Yes & 100 & 0 \\
\hline & No & 0 & 100 \\
\hline \multirow[t]{2}{*}{ Transportation of animal } & By Train & 55 & 0 \\
\hline & By Truck & 45 & 0 \\
\hline \multirow[t]{4}{*}{ Marketing Area } & North eastern area of India & 55 & 0 \\
\hline & Delhi & 30 & 0 \\
\hline & Gurugram & 15 & 0 \\
\hline & Local Market & 0 & 100 \\
\hline
\end{tabular}


Table.5 Percentage of healthcare practices in the area

\begin{tabular}{|c|c|c|c|}
\hline \multirow{2}{*}{\multicolumn{2}{|c|}{ Variables }} & \multirow{3}{*}{$\begin{array}{c}\text { Organized } \\
\text { Per cent } \\
20\end{array}$} & \multirow{3}{*}{$\begin{array}{c}\text { Unorganized } \\
\text { Per cent } \\
0\end{array}$} \\
\hline & & & \\
\hline \multirow[t]{3}{*}{ Deworming } & Regular & & \\
\hline & Irregular & 80 & 0 \\
\hline & Never & 0 & 100 \\
\hline \multirow[t]{2}{*}{ Vaccination } & Yes & 0 & 0 \\
\hline & No & 0 & 100 \\
\hline \multirow[t]{2}{*}{ Fe injection/ tablet to piglets } & Yes & 65 & 0 \\
\hline & No & 35 & 100 \\
\hline \multirow[t]{2}{*}{ Removal of needle teeth } & Yes & 70 & 0 \\
\hline & No & 30 & 100 \\
\hline \multirow[t]{2}{*}{ Veterinary Aid available } & Satisfactory & 15 & 0 \\
\hline & Poor & 85 & 100 \\
\hline \multirow[t]{3}{*}{ Mortality of pigs } & Upto 1 month & 60 & 55 \\
\hline & $1-3$ month & 30 & 22.5 \\
\hline & Above 3 month & 10 & 22.5 \\
\hline \multirow[t]{3}{*}{ Causes of piglet mortality } & Piglet anaemia & 45 & 0 \\
\hline & Crushing of piglets & 35 & 0 \\
\hline & Unknown diseases & 20 & 100 \\
\hline \multirow[t]{3}{*}{ Prevalence of disease } & Diarrhea & 45 & 77.5 \\
\hline & Skin disease & 25 & 22.5 \\
\hline & Influenza & 30 & 0 \\
\hline \multirow[t]{2}{*}{ Isolation of sick animal } & Yes & 100 & 0 \\
\hline & No & 0 & 100 \\
\hline \multirow[t]{3}{*}{ Cleaning of pig sty } & Daily & 85 & 0 \\
\hline & Alternate day & 15 & 25 \\
\hline & Weekly & 0 & 75 \\
\hline \multirow[t]{2}{*}{ Burial of carcass } & Yes & 100 & 100 \\
\hline & No & 0 & 0 \\
\hline
\end{tabular}

In organized sector, feeding of hotel waste, the hostel waste and combination of both were provided as feed by $35 \%, 40 \%$ and $25 \%$ respondents respectively and those feeds were consist of damaged vegetables, bread, chapatti, Rice and mixture of leftover food. Regarding the purchasing of the food in organized sector it was carried out by direct purchasing (45\%) and by involvement of the middle man $(55 \%)$. The quantity of the feed provided to the pig was $20-30 \mathrm{~kg}, 30-50 \mathrm{~kg}$ and $50-70 \mathrm{~kg} /$ day by $35 \%, 55 \%$ and $10 \%$ of respondents, respectively. Regarding the healthcare practices it was observed that the respondents followed the deworming practices in organized sector only in which $80 \%$ respondents had irregular deworming schedule and only 20\% did deworming regularly. The Vaccination was also practiced by respondent of organized sector. Supplementation of iron injection was also practiced in organized sector only by $65 \%$ respondents (Table 5). In organized farm the practice of removal of needle teeth done by $70 \%$ of respondents and in unorganized farm this is not practiced by any farmer. The disposal of carcass by burial method was practiced by all the respondents irrespective of organized and unorganized sector. The present findings more or less were in support 
of Kumar et al., (2004), Deka et al., (2007), Roy (2014) and Ritchil et al., (2013).

According to the result findings (Table 6) it was observed that the selling weight of the pig in organized farm were $100 \mathrm{~kg}$ and $120 \mathrm{~kg}$ and majority of respondents $(75 \%)$ sell their pig at $100 \mathrm{~kg}$ body weight whereas $25 \%$ respondents sell at $120 \mathrm{~kg}$ body weight, in contrast with unorganized farm where $100 \%$ respondents sell their pig at $50-60 \mathrm{~kg}$ body weight, according to their need. The marketing age of pig in organized farm was 910 months and $10-12$ months. $80 \%$ of the respondents were selling their pig at 10 -12 month of age because of the market weight of pig was achieved at this age (10-12 month) whereas in unorganized sector the market age of the pig was 5-7 month as well as their need.

It is concluded from the present study among various livestock species, pig is considered as one of the most meat producing animal around the world, pork contributes highest (36.57\% of total meat production) towards the meat basket of the world, Share of meat production from livestock sector $(1.96 \%)$ of India towards world meat production is very less and contribution of piggery is even very negligible. Lack of knowledge about scientific breeding, feeding, healthcare management etc. along with unorganized marketing facility and various severe constraints faced by farmers. Piggery sector has not come up well, despite of many more advantages, benefits and huge demand of pork in the country.

\section{References}

Ajala, M.K., Adesehinwa, A.O.K. and Mohammed, A.K. (2007). Characteristics of small holder pig production in Southern Kaduna area of Kaduna state, Nigeria. AmericanEurasian Journal of Agriculture \&
Environmental Science. 2(2): 182-188.

Deka, R., Thorpe, W., Lapar, M.L. and Kumar, A. (2007). Assam's pig subsector: current status, constraints and opportunities. Project report, Markets theme, International Livestock Research Institute, Nairobi, Kenya.

Government of India (2016). Basic animal husbandry statics. Department of animal husbandry and dairying ministry of agriculture.

Fualefac, D.H., Raphae, K.J., Bime M.J., Ndebi G., Yemele, F., Zoli, P.A., Manjeli, Y., Teguia, A. and Tchoumboue, J. (2014). Socioeconomic and technical characteristics of pig farming in the urban and peri - urban zone of Dschang - West region of Cameroon. Journal of Agriculture and Food Sciences. 2(1): 11-20.

Kumar, R.; Pal, P.P.; Prakash, N. and Naskar, S. (2004). Livestock management practices by the small holders of north eastern region. Indian Journal of Animal Sciences. 74(8): 882-886.

Machebe, N.S., Onyekuru, N. A. and and Ekweogu, N. (2009). Socio-economic factors affecting pig production in Enugu state Nigeria. Journal of Agriculture, Forestry and the Social Sciences (JOAFSS).7(1):41-49.

Ritchil, C.H., Faruque, M.O., Tabassum, F., Hossain, M.M. and Bhuiyan, A.K.F.H. (2013). Socio-economic status of pig rearers and management system of native pigs in Bangladesh. Indian Journal of Animal Sciences. 83(11): 1226-1228.

Roy, R. (2014). Healthcare and Management Practices among Pig farmers in hill zone of West Bengal. Indian Journal of Hill Farming.27(1):140-144.

Sasikala, V., Kumaravel, P. and Mathialagan, P. (2012). A study on socio-economic status of pig farmers in Kancheepuram 
district of Tamilnadu state. International Journal of research in commerce, economics and management.2(3):61-64.

Vicente R.E., Manuel S.R., Antón G. and
Gustavo A.G.C. (2010). Feed conversion rate and estimated energy balance offree grazing Iberian pigs. Elsevier livestock science.132:152156.

\section{How to cite this article:}

Nanda, B., M.P. Poonia, A. Sharma, S. Rajoria and Sharma, S. 2018. Pig Management System in Organized and Unorganized Farm in Jaipur and Alwar District of Rajasthan, India. Int.J.Curr.Microbiol.App.Sci. 7(08): 2779-2786. doi: https://doi.org/10.20546/ijcmas.2018.708.292 